\title{
PARADOKSALITAS PEMOSISIAN PEREMPUAN NOVEL COLOMBA KARYA PROSPER MERIMEE
}

\author{
Wening Udasmoro \\ Fakultas Ilmu Budaya Universitas Gadjah Mada \\ Email: udasmoro@ugm.ac.id
}

\begin{abstract}
Women have been narrated by men authors since classical literature; this has continued into contemporary literature. In the 19th century, many authors were interested in narrating and positioning women in their novels. This period can be considered one of transition, in which traditionality and modernity were contested because of influences from the industrial revolution and many other social movements in Europe. This period was also one of challenge, with the appearance of Gustave Flaubert's novel Madame Bovary, which was questioned because of moralistic issues. If in the early 19th century traditionality was represented by Eugénie Grandet and Balzac's figures of woman, but in the middle of the century Flaubert dealt with freedom of sexuality, what discourses were presented in between these two different periods? This article aims at explaining the bridging of the gap between the symbols of traditionality and modernity, especially through the representation of women. Mérimée's novel, Colomba, depicts the agency of a woman named Colomba. In this novel, Mérimée not only showed the position of women vis à vis men in parental or conjugal relation, like in the novels Eugénie Grandet or Madame Bovary. Rather, the author attempted to look at the relationship between masculinities and femininities in a Corsican context, in which the intersection of gender and social class (as well as traditions) was different than in the Parisian context. The relation between the novel and the social structure in the 19th century Europe plays an important part in the discussion and explanation of the relationship between the literature and social narration of that period.
\end{abstract}

Keywords: Paradoxality, Women, Mérimée, French, Literature, 19th century.

\begin{abstract}
ABSTRAK
Perempuan banyak dinarasikan oleh para pengarang Prancis sejak masa karya sastra klasik sampai kontemporer. Abad ke-9 merupakan abad ketika para pengarang tertarik untuk menarasikan dan memosisikan perempuan dalam karya-karya mereka. Abad ke-19 sendiri merupakan abad transisi saat tradisionalitas dan modernitas mulai dipertentangkan akibat pengaruh revolusi industri dan gerakangerakan sosial lain di Eropa. Abad ini juga merupakan abad yang penuh dengan kontradiksi setelah munculnya novel Madame Bovary karya Flaubert yang di dalamnya isu moralitas dipertanyakan. Jika pada masa awal abad tradisionalitas muncul secara ketat yang direpresentasikan oleh karya-karya Balzac seperti Eugénie Grandet dan pada tengah abad gaya hidup bebas direpresentasikan oleh Bovary karya Flaubert, bagaimana dengan karya-karya terkait perempuan lain yang berada di antara kedua karya tersebut? Artikel ini bertujuan untuk menjelaskan bridging gap antara kedua fenomena besar sastra yang berbeda tersebut terutama terkait dengan pemosisian perempuan. Karya Mérimée, Colomba, menceritakan tentang agensi perempuan bernama Colomba. Dalam karyanya ini, Mérimée tidak hanya sekedar memosisikan perempuan vis à vis laki-laki dalam hubungan parental dan konjugal, seperti yang ada di dalam konteks Eugénie Grandet atau Madame Bovary tetapi terkait dengan konteks hubungan maskulinitas dan femininitas dengan aspek etnisitas dan interseksionalitas kelas sosial dalam budaya
\end{abstract}


Korsika yang sangat berbeda dengan prinsip hidup Parisien. Hubungan karya dengan struktur sosial pada masa itu di Eropa menjadi bagian dari diskusi untuk menjelaskan keterkaitan antara sastra sebagai bagian narasi sosial pada masa itu.

Kata Kunci: Paradoksalitas, Perempuan, Merimee, Sastra, Prancis Abad ke-19.

One mustn't judge Corsican morals by our little European ideas. Here a bandit is generally the most honest man in the region

Gustave Flaubert

\section{PENGANTAR}

Novel Colomba ditulis pertama kali oleh Prosper Mérimée dalam bentuk cerita pendek pada tanggal 1 Juli 1840 dan diterbitkan oleh Revue des deux mondes. Karya ini kemudian diterbitkan dalam bentuk novel pada tahun 1841. Hampir semua pengarang besar pada abad ke-19, antara lain Balzac, Flaubert dan Mérimée, mencoba menjelaskan posisi perempuan dalam relasi mereka dalam keluarga maupun dalam relasi sosial secara lebih luas. Salah satu karya masterpiece Balzac adalah Eugénie Grandet diterbitkan pada tahun 1833. Novel ini terbit lima belas tahun sebelum novel kontroversial Madame Bovary yang diterbitkan pada tahun 1856. Madame Bovary sendiri merupakan novel yang memunculkan banyak kritik terutama karena isi cerita yang dianggap tidak bermoral sehingga menyebabkan penerbit novel tersebut dipenjara karena dianggap tidak mematuhi aturan moral pada waktu itu (Udasmoro, 2011a: 2).

Eugénie Grandet karya Balzac adalah gambaran tradisionalitas dan domestifikasi perempuan yang erat dengan penggambaran peran mereka dalam ruang privat. Hal ini tentu berkebalikan dengan Madame Bovary yang memunculkan perempuan dengan peran dominan di ranah publik dan berkuasa di ranah privat serta diekspos seksualitasnya. Jika Madame Bovary direpresentasikan oleh pengarang sebagai perempuan yang memiliki dominasi kuat dalam hubungan dengan lakilaki, yakni suaminya yang secara kelas sosial sebetulnya lebih tinggi daripada dirinya, sebaliknya dengan Eugénie Grandet. Eugénie dicitrakan sebagai perempuan dari keluarga kaya yang subordinat dalam hubungannya dengan laki-laki yang dalam hal ini adalah ayahnya, Monsieur Grandet dan pacarnya, Charles.

Ada dua kutub representasi dan posisi perempuan yang menjadi ajang kontestasi. Menjadi perempuan seperti apa yang diposisikan oleh pengarang pada abad ke-19 adalah pertanyaan besar. Novel-novel di Prancis memiliki arah rujukan ideologis pengarang yang berbeda mengenai individualisasi, subjektivitas dan modernitas yang berhadapan dengan kehidupan sosial yang lebih menekankan pada aspek normatif yang masih dipercayai. Dalam konteks ini, terlihat bahwa dalam waktu 23 tahun, ada transformasi besar representasi perempuan dalam novel-novel Prancis. Perempuan bukan lagi entitas yang homogen dan direpresentasikandengan carayangsama. Kehidupan sosial yang berubah dengan adanya industrialisasi dan pertanyaan-pertanyaan kritis pada isu moralitas dan agama menjadi aspek-aspek yang dijadikan rujukan oleh para pengarang dalam menggambarkan perempuan. Tubuh perempuan sebagai salah satu aspek yang dikontrol oleh rejim-rejim normatif sebelumnya mulai dipertanyakan. Detradisionalisasi dalam kehidupan sosial di Prancis menempatkan perempuan dalam gambaran yang semakin plural. Mereka tidak lagi sama, seperti halnya karya-karya pada abad-abad sebelumnya.

Abad ke-19 merupakan abad ketika gerakan-gerakan sosial dan pemikiran ideologis muncul karena perubahan-perubahan besar dalam konteks ekonomi, sosial dan politik di Eropa, termasuk di Prancis. Revolusi industri di Barat yang terjadi antara tahun 1750 sampai 1850 membawa perubahan dalam hubungan baik konjugal, familial maupun sosial antara perempuan dan lakilaki. Menurut Robert B. Holtman (1979), seorang sejarawan ahli Napoleon, kekuasaan Napoleon di seluruh Eropa dari tahun 1803 sampai 1815 juga membawa dampak juridis yang sangat penting. Code Civil Napoleon 
(Undang-Undang Napoleon) yang disahkan pada tahun 1804 merupakan sebuah UndangUndang baru yang menggantikan UndangUndang feodal, yakni Codex Maximilianeus bavaricus civilis (Bavaria, 1756), Allgemeines Landrecht (Prusia, 1792) dan West Galician Code, (Galicia, 1797). Holtman juga berargumen bahwa Code Civil Napoleon ini menjadi salah satu produk juridis yang mempengaruhi seluruh dunia, terutama dalam mengeradikasi undang-undang feodal dan tradisional.

Salah satu konsekuensi dari berbagai perubahan tersebut, keluarga bukan lagi dijelaskan sebagai hubungan hirarkis absolut di mana laki-laki menjadi hegemonic masculine. Konteks hegemonic masculinities ini dijelaskan oleh Connell (1995) sebagai hubungan hirarkis gender di mana yang maskulin, yakni laki-laki heteroseksual diposisikan sebagai yang memiliki legitimasi hegemonis dan sebagai pemenang secara taken for granted dalam segala pertarungan. Kehadiran perempuan, meskipun masih dalam narasi laki-laki, menjadi lakon baru dalam novel-novel di Prancis. Perempuanperempuan dihadirkan secara khusus oleh para pengarang laki-laki sebagai usaha, antara untuk menunjukkan kontroversikontroversi keberadaan mereka di ruang publik yang dianggap akan semakin terbuka.

Sementara itu, dengan adanya revolusi industri (1750-1780), yang ditandai pula dengan kenaikan jumlah penduduk yang besar karena perbaikan sistem sanitasi dan kesehatan serta kenaikan angka kelahiran, ada dinamika tersendiri dalam konteks kehidupan sosial yang juga dituliskan dalam novel. Salah satu aspek penting misalnya adalah mengenai bandit dan vendetta (balas dendam) yang di dalam konteks sosial menjadi pertentangan ide tradisional dan modernitas.

Bandit dan Vendetta adalah bagian dari tradisi yang dalam konteks modern dianggap sebagai perilaku barbar dalam masyarakat Eropa, dan mulai dipertanyakan eksistensinya. Dua aspek ini bersifat sangat spesifik karena mengenaikultur etnis tertentu. Korsika, mengalami masa dimana bandit dan vendetta merupakan bagian penting dalam sejarah daerah tersebut. Perbanditan dan vendetta menjelaskan bahwa maskulinitas memiliki ruang yang besar dalam ranah publik karena laki-lakilah yang melakukan dua aktivitas tersebut. Jika bandit identik dengan laki-laki, di dalam novel Colomba, tokoh yang paling berpengaruh dalam hal ini justru adalah seorang perempuan, yakni Colomba. Mengapa Colomba yang seorang perempuan ini direpresentasikan sebagai yang memiliki kekuasaan besar dalam dunia maskulin, bandit dan vendetta menjadi aspek yang menonjol untuk dibahas. Bagaimana pengarang memosisikan seorang perempuan yang memiliki agensi yang sangat kuat di wilayah yang dikuasai oleh para bandit yang sangat maskulin tersebut. Melihat persoalan tersebut, hal penting yang dapat dipertanyakan adalah sebagai berikut.

Pertama, posisi kekuasaan perempuan seperti apa yang digambarkan oleh pengarang mengingat bahwa ada kekuasaan hegemonic masculities terkait vendetta dalam kultur Korsika? Kedua, mengapa perempuan digambarkan dengan posisinya yang sangat kuat dalam kultur maskulin tersebut? Ketiga, bagaimana hubungan pemosisian tersebut dengan struktur masyarakat pada abad ke-19 di Korsika?

Tujuan artikel ini adalah melihat interseksi hubungan antara pemosisian perempuan dengan situasi perubahan sosial pada abad ke-19. Hal ini dilakukan untuk melihat lebih lanjut aspek-aspek ideologis yang ditawarkan pengarang terkait dengan situasi sosial tersebut. Artikel ini juga sekaligus untuk mengetahui apakah pemosisian perempuan yang tinggi dalam karya tersebut merupakan respon positif terhadap perubahan sosial dimana perempuan mulai dibicarakan dalam narasi ataukah pemosisian ini merupakan kritik terhadap perubahan sosial itu sendiri? 


\section{PEMBAHASAN}

\section{Relasi Gender dan Pemosisian Perempuan dalam Kalangan Kelas Atas Korsika}

Relasi gender seringkali dimaknai sebagai sebuah relasi struktur dimana ada pihak yang mendominasi dan yang didominasi. Persoalannya bahwa yang mendominasi dan didominasi tersebut dianggap memiliki pattern yang sama, bahwa laki-laki adalah yang mendominasi dan perempuan adalah yang didominasi (Moller Okin, 1989). Pandangan ini secara historis dapat dipahami mengingat bahwa ada pola-pola semacam itu dalam perjalanan relasi laki-laki dan perempuan, terutama dalam konteks Eropa. Second Wave of Feminism, terutama dalam tulisan-tulisan Shulamith Firestone yang berjudul The Dialectic of Sex, Betty Friedan (1963) yang berjudul Feminine Mystique, Carole Pateman (1988) yang berjudul The Contract Sexual, Simone de Beauvoir (1977) dengan judul Le Deuxième Sexe dan Sylvia Walby (1989) dengan judul Theorising Patriarchy seperti bersepakat bahwa ada sebuah rezim gender yang disebut dengan rezim patriarki yang mengkonstruksi sistem tersebut. Shulamith Firestone menjelaskan bahwa sumber patriarki yang membelenggu perempuan adalah akibat perbedaan fisik dan biologis antara laki-laki dan perempuan. Perempuan dengan tubuh biologisnya yang dapat hamil dan melahirkan menempatkannya pada ruang yang tidak sama dengan laki-laki.

Feminis lain, yaitu Betty Friedan menjelaskan dalam bukunya berjudul The Feminine Mystique bahwa perempuan terbelenggu secara psikologis dalam era industrialisasi karena keberadaan mereka di dua ruang yang berbeda, yaitu di ruang privat dan di ruang publik. Sementara itu, Sylvia Walby menjelaskan mekanisme sistem patriarki yang dia anggap berada pada level privat maupun publik. Tidak kalah pentingnya adalah pandangan Simone de Beauvoir yang melihat perempuan seperti sex kedua. Perempuan selalu berada pada level kedua setelah laki-laki. Mereka adalah liyan. Mereka tidak lahir, mereka dibuat oleh sistem laki-laki.
Jika feminisme gelombang kedua memiliki perjuangan untuk membawa perempuan pada level yang emansipatoris, hal tersebut dikritisi lebih jauh oleh Chandra Mohanty (1988: 62) yang melihat bahwa tidak pernah ada pola yang sama dalam relasi gender. Tidak pernah ada pemenang yang selalu menang dalam setiap pertempuran. Tidak semua laki-laki akan menguasi perempuan. Yang menjadi pertanyaan adalah siapa mereka yang berkuasa tersebut? Lakilaki belum tentu akan menjadi penguasa ketika berhadapan dengan perempuan dari kalangan tertentu. Perempuan kelas atas, misalnya, seringkali memiliki posisi yang lebih menguntungkan daripada laki-laki kelas bawah. Perempuan yang berasal dari kelompok etnis penguasa, dapat memiliki bargaining position yang kuat dibandingkan laki-laki dari kelompok minoritas yang marjinal. Dengan demikian, tidak hanya persoalan individu laki-laki berhadapan dengan individu perempuan dalam hal ini. Selalu ada kesempatan dimana lingkungan sosial individu tersebut berperan di dalam memosisikan relasi laki-laki dan perempuan tersebut di dalam masyarakat.

Pandangan Chandra Mohanty ini yang akan dijadikan rujukan sebagai kerangka berpikir meskipun rezim maskulin yang ditawarkan para feminis sebelumnya tetap dilihat sebagai rujukan mengingat Abad ke19 merupakan babak awal munculnya narasi tentang perempuan yang masih terdominasi oleh cara berpikir laki-laki. Dalam novel Colomba, misalnya, narasi perempuan sebagai yang kuat dan memiliki keberanian adalah hal baru dalam sastra Prancis. Persoalannya, Colomba merupakan representasi dari kalangan kelas atas yang dalam kehidupan sehari-hari para perempuannya memang memungkinkan untuk berkuasa.

Persoalan teoritis lain yang perlu dijelaskan adalah mengenai konsep maskulintas yang merupakan nilai yang tidak hanya ada pada laki-laki, tetapi juga ada dalam diri perempuan. Connell (1998: 5) lebih menyetujui bahwa yang menjadi persoalan bukan laki-laki dan perempuan sebagai entitas 
tetapi lebih pada nilai maskulin dan feminin yang bersirkulasi yang dapat diaplikasikan baik oleh laki-laki maupun perempuan. Lakilaki dan perempuan sebenarnya tidak secara taken for granted memiliki nilai maskulin dan feminin. Ada satu kompleksitas yang seringkali saling dipertukarkan.

Hubungan nilai maskulin dan feminin sebagai cara berpikir gender dan bukan hanya sekedar persoalan laki-laki dan perempuan saja menjadi aspek yang tidak kalah penting. Selain itu, interseksi dengan aspek etnisitas dan kelas sosial menjadi interseksi yang lain. Bangunan berpikir di atas menjelaskan adanya hubungan antara gender, etnisitas, dan kelas sosial. Gender menjadi aspek yang sangat penting karena masyarakat selalu bersifat gender. Maksudnya, segala aspek dalam kehidupan sosial dibuat bergender. Akan tetapi, gender tersebut tidak bersifat otonom. Selalu ada hubungan gender dengan kategori sosial yang lain. Konteks novel Colomba bahwa kategori sosial yang lain tersebut adalah etnisitas dan kelas sosial atas. Etnisitas penting karena setting daerah Korsika adalah sesuatu yang disengaja oleh pengarang dalam melihat hubungan gender. Ada sesuatu yang luar biasa dalam karya ini. Jika perempuan masih dilemahkan tujuh tahun sebelumnya dalam tulisan Balzac mengapa tiba-tiba muncul Colomba sebagai yang lebih maskulin daripada para tokoh yang maskulin dalam konteks cerita tersebut. Selain itu, mengapa perempuan itu adalah Colomba yang diciptakan sebagai seorang gadis yang melawan hirarki kekuasaan gender hegemonis dan kalangan atas lain yang berkuasa.

\section{Menjadikan Laki-Laki dan Vendetta dalam Konteks Korsika}

Hal paling mendasar sebagai sesuatu yang baru dalam artikel ini adalah perspektif interseksionalitas ganda. Jika dalam kajian feminisme, interseksionalisme dilakukan dengan menginterseksikan gender dengan kategori-kategori sosial yang lain, misalnya etnisitas dan kelas sosial (Mohanty, 1988: 65), artikel ini menginterseksikan pula dengan persoalan maskulinitas dan femininitas sebagai tools baru dalam gelombang feminisme kontemporer. Maskulinitas dan femininitas ini tidak sejajar dengan laki-laki dan perempuan tetapi lebih sebagai nilai-nilai maskulin dan feminin yang dapat melekat baik kepada laki-laki maupun perempuan.

Novel Colomba, representasi maskulinitas justru dilekatkan pada sosok Colomba dari keluarga della Rebbia, gadis perempuan yang akan melakukan balas dendam atas kematian orangtuanya yang dibunuh oleh keluarga Barricini. Ayah Colomba dibunuh oleh advokat Barricini di depan matanya. Si pembunuh bebas tanpa proses hukum yang jelas. Pada awalnya, Colomba melimpahkan vendetta itu kepada kakak laki-lakinya, yakni Orso della Rebia karena sebagai anak lelaki tertua, dalam tradisi Korsika, dialah yang berhak melakukan vendetta. Akan tetapi, Orso enggan melakukan vendetta. Orso yang merupakan serdadu Napoleon terikat dengan peraturan negara untuk tidak melakukan praktik yang tidak bisa dilakukan sebagai orang Prancis. Hukum Napoleon (Code Civil Napoleon) yang sudah diberlakukan sejak 1804 telah menggantikan peraturan sebelumnya yang dianggap sebagai warisan feodal dan tidak berbudaya. Atas desakan dan strategi Colomba, akhirnya Orso melakukan vendetta seperti yang diharapkan Colomba.

Pada novel ini, dua perempuan yang penting menempati posisi yang berbeda. Pendapat modernitas dengan menolak vendetta ini dipengaruhi oleh seorang perempuan Inggris, yakni Miss Lidya Nevil, yang baru dikenal Orso di dalam kapal dalam perjalanannya ke Korsika. Berikut ini cuplikan pengaruh dari pandangan yang menentang barbarisme tersebut.

"Non, monsieur della Rebbia, dit-elle en l'arrêtant; je sais que vous êtes un "gentleman" Croyais-vous que je puisse, un jour, devenir un meurtrier?

- Non; mais je vous ai parlé parce que j'ai compris que je dois vous aider au moment où vous retournez dans votre pays. Vous aurez le courage de ne pas suivre ces vieilles habitudes, je le sais. Allons! Ne parlons plus de ces choses laides; elles 
me font mal à la tête; et d'abord il est bien tard... Me pardonnez-vous? ... Bonsoir.

-Mademoiselle, dit Orso, il y a des moments ou les vieilles habitudes du pays se réveillent en moi. Quelquefois, quand je pense à mon pauvre père..., alors de terribles idées s'installent en moi... Vous les avez chasses... Merci! Merci!...

“Tidak, tuan della Rebbia, kata (Nona Lidya) sambil menghentikannya; saya tahu anda adalah seorang "gentleman"

-Percayakah anda bahwa suatu saat saya dapat menjadi seorang pembunuh?

-Tidak; tapi saya mengatakan kepada anda karena saya yakin saya harus menolong anda ketika anda pulang ke negara anda. Anda akan punya keberanian untuk tidak melanjutan tradisi kuno itu, saya paham. Ayolah! Jangan bicarakan hal yang jelek itu lagi; saya jadi sakit kepala, selain itu .. ini sudah malam. Izinkan saya pergi? Selamat malam -Nona, kata Orso, ada kalanya tradisi kuno negara saya itu ada di benak saya. Kadang, ketika saya memikirkan ayah saya, ide gila itu muncul... Anda telah mengusirnya... Terima kasih! Terima kasih!

Ada semacam persuasi dari Miss Lidya yang berasal dari Inggris yang mulai membicarakan mengenai praktik barbarisme yang ingin ditolaknya yang kemudian mempengaruhi Orso della Rebbia. Keberadaan Lidya yang orang Inggris yang seakan memberikan persuasi moral kepada seorang laki-laki Korsika menjelaskan adanya poros setral dan periferi di mana perempuan di sini berada pada poros sentral representasi budaya Eropa. Sementara itu, Orso yang merupakan laki-laki Korsika berposisi di pereiferi dengan representasi gambaran budaya yang masih biadab.

Sementara itu, Colomba mengetahui bahwa Orso enggan melakukan vendetta sehingga ia melakukan berbagai startegi, antara lain dengan mengantar kakaknya ke tempat ayah mereka dibunuh. Colomba berhasil mempengaruhi Orso untuk membunuh anak-anak keluarga Barricini. Jadi, dalam hal ini ada pertentangan nilai-nilai modernitasdantradisionalitasyang dilakukan oleh tokoh-tokoh yang berbeda, yaitu Orso, Colomba dan Miss Lidya. Orso adalah representasi modernitas yang mengikuti aturan negara yang berlaku. Tindakannya didukung oleh Miss Lidya, gadis Inggris yang mempertanyakan persoalan barbarisme di dalam tradisi Korsika. Sementara itu, Colomba adalah representasi tradisionalitas yang sudah dianggap sebagai praktik barbar dalam pandangan orang Prancis Parisien dan juga pandangan Eropa pada umumnya. Menariknya adalah ide untuk mengkonfrontasi modernitas dan kebiasaan tradisional yang dianggap jelek itu datang dari seorang perempuan yang berasal dari negara Eropa lain.

Gambaran representasi modernitas dan tradisionalitas ini menjelaskan hubungan gender dimana laki-laki dan perempuan direpresentasikan sebagai figur yang modern dan yang tradisional. Akan tetapi, apabila modernitas dan tradisionalitas tersebut dihubungkan dengan persoalan gender yang lain, yakni maskulinitas dan femininitas, ada sesuatu yang tidak sejalan. Jika Orso adalah laki-laki yang merepresentasikan modernitas, maka itu adalah hal yang biasa dalam kritik feminisme karena laki-laki selalu dihubungkan dengan konteks modernitas, ilmu pengetahuan, teknologi dan sebagainya. Akan tetapi, paradoksalitas yang muncul adalah bahwa dengan menjadi modern, maka Orso kehilangan maskulinitasnya. Dia rela menjadi tidak maskulin (sebagai seorang della Rebia yang melakukan vendetta) daripada harus kehilangan aspek modernitasnya. Selain itu, ide modernitas itu juga dimiliki oleh seorang perempuan lain, yakni Miss Lidya Nevil yang berasal dari Inggris. Ada sosok other yang mencoba menjelaskan ide modernitas ini kepada Orso yang tadinya berpegang kepada tradisionalitas. Dengan demikian, tokoh laki-laki ini adalah subjek yang terpengaruh oleh subjek perempuan lain, yang notabene adalah outsider atau liyan.

Ketika Orso kemudian pada akhirnya melakukan vendetta, itu pun dilakukan atas pengaruh perempuan yang memiliki jiwa maskulin, yakni Colomba. Orso adalah subjek yang melakukan vendetta karena perintah dari subjek lain, yakni adiknya, Colomba. 
Jadi, dari penggambaran Mérimée di dalam karyanya ini, posisi Orso sebagai laki-laki sebenarnya seperti halnya tangan, yang otaknya adalah para perempuan, yakni Miss Lidya dan Colomba. Orso adalah seorang serdadu berpangkat kolonel, tetapi dalam sebuah urusan yang maskulin, dia dipaksa menjadi maskulin oleh perempuan yang dimaskulinkan oleh pengarang. Jadi, dalam hal ini ada kontestasi maskulinitas yang kompleks. Ada maskulintas dan femininitas yang bergerak tidak stabil, bahkan dalam konteks sosial yang dianggap patriarkal dan barbar sekalipun.

Sementara itu, Colomba adalah representasi perempuan yang menjaga tradisi meskipun tradisi tersebut dalam konsep Eropa dipandang sebagai praktik barbar. Berikut ini adalah gambaran Colomba yang terlihat dari dua sampul gambar novel Colomba dari dua penerbit yang berbeda. Sampul gambar yang sebelah kiri merupakan versi dari edisi Spirale sementara yang sebelah kanan merupakan versi Livre de Poche.

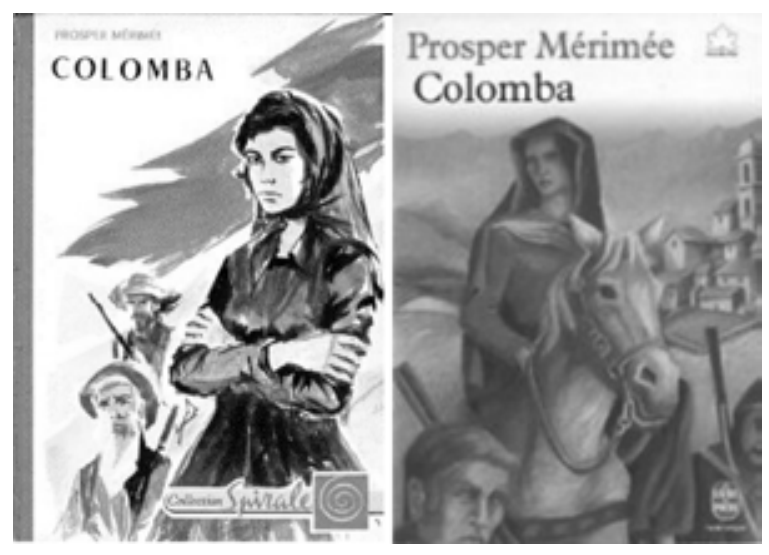

Courtesy: www.novel-historique.fr Gambar 1

Cover Novel

Dari dua gambaran sampul tersebut, terlihat bahwa sosok Colomba, seperti halnya di dalam novel, digambarkan masih sebagai seorang perempuan tetapi ada simbol-simbol lain yang dijelaskan sebagai sebuah shared meaning dan penerjemahan penerbit buku terhadap novel Colomba karya Mérimée, terutamaterkaitaspek-aspekmaskulinitasnya. Colomba digambarkan sebagai sosok yang sangat perkasa sementara para laki-laki yang ada di sekitarnya digambarkan justru lebih subordinat. Gambaran ini di satu sisi seakan menjadi simbol baru kekuasaan perempuan pada waktu itu, yakni mengubah tradisi bahwa perempuan adalah yang lemah dan tidak berdaya. Sementara itu, dengan dikuatkannya peran perempuan sebagai yang maskulin, para laki-laki, terutama tokoh paling penting, yakni Orso della Rebia dilemahkan dan diposisikan seakan sebagai perempuan. Orso dianggap tidak memiliki hasrat vendetta, dia dianggap membunuh musuh ayahnya karena memenuhi vendetta dari Colomba. Sebagai laki-laki dia tampak tidak bertanggung jawab dalam persoalan vendetta ini. Ada dua argumen yang dapat dikemukakan di sini mengkritisi argumen di atas.

Pertama, pengarang adalah Prosper Mérimée, menulis novel tersebut berdasarkan pengalaman individunya pada tahun 1839 sebagai inspektur general Monumen sejarah di Korsika. Korsika merupakan wilayah Prancis yang berbatasan dengan Italia. Ada dua wilayah Prancis yang masih memiliki tradisi vendetta. Dia memiliki pengalaman dengan cerita vendetta yang terjadi hanya enam tahun sebelum kedatangannya di Korsika. Jadi, cerita novel ini sebetulnya adalah bagian dari pengalaman pribadi Mérimée. Dalam pengalaman tersebut, pengarang mendapatkan sebuah cerita mengenai balas dendam yang dilakukan oleh dua keluarga terkenal di Korsika yang terjadi pada tahun 1833 (Haedens, 1970). Pada waktu itu, dua keluarga, yakni keluarga Carabelli dan Durazzo dari desa Fozzano melakukan tradisi vendetta tersebut. Mérimée juga berkenalan dengan Colomba Carabelli yang menjadi model dalam novelnya.

Pengarang kemudian mencoba menelusuri vendetta tersebut dan mengekplorasinya di dalam karyanya. Satu hal berbeda adalah bahwa tokoh perempuan yang melakukan vendetta dalam kejadian sesungguhnya bukan seorang gadis remaja tetapi seorang perempuan berusia 57 tahun. Kejadian sesungguhnya adalah persoalan 
ketersinggungan dari salah satu pihak. Pada tahun 1830 salah seorang anak laki-laki dari keluarga Durazzo menolak mengawini anak gadis keluarga Carabelli yang sudah dijanjikannya untuk dinikahi. Pada tanggal 26 Juni 1830, satu orang dari keluarga Durazzo dibunuh dan dua anak dari keluarga Carabelli dibunuh. Colomba memobilisasi keluarganya untuk melakukan balas dendam dan pada bulan Desember 1980 empat orang meninggal, yakni dua orang laki-laki dari keluarga Durazzo dan dua orang laki-laki dari keluarga Carabelli. Kisah Colomba ini dikenang oleh Korsika dan kuburannya dijadikan monumen.

Kedua, kengerian pengarang terhadap vendetta itu dimunculkan dalam sosok perempuan, yaitu Colomba, yang secara pribadi dia kenal, tetapi digambarkan dengan sosok Colomba yang lebih muda. Bisa dibayangkan bahwa masalah balas dendam yang bersifat maskulin itu lebih banyak dilakukan oleh laki-laki daripada perempuan. Akan tetapi, justru perempuan yang digambarkan memiliki harapan untuk melakukan vendetta yang dianggapnya mengerikan tersebut. Ada berbagai macam cerita vendetta di Korsika, tetapi justru tokoh perempuan Colomba ini yang diangkat ceritanya. Hal ini karena pada saat pengarang berada di Korsika, vendetta kedua keluarga tersebut baru beberapa tahun berlangsung. Jika cerita vendetta yang dilukiskan para tokohnya adalah laki-laki, maka tidak akan ada hal yang terlalu istimewa. Akan tetapi, ketika yang diangkat adalah seorang perempuan, maka hal ini menjadi tampak memiliki nuansa semangat zaman pada abad ke-19, karena pada waktu itu para pengarang laki-laki banyak yang memunculkan narasi perempuan.

Kemunculan narasi perempuan ini menjadi penting karena perempuan, yang dalam hal ini adalah Colomba, menjadi subjek atau pelaku dari vendetta tersebut. Akan tetapi, di sisi lain, Colomba hanya menjadi tokoh protagonis di dalam cerita. Dalam konteks Eropa secara lebih luar, seperti yang dikatakan Flaubert, justru menunjukkan adanya penstereotipan terhadap orangorang Korsika. Kalimat Flaubert berikut ini menjadi terlalu kompleks untuk menjelaskan kepahlawanan Colomba.

One mustn't judge Corsican morals by our little European ideas. Here a bandit is generally the most honest man in the region

Apabila membaca kalimat di atas, ada sebuah judgement keras bahwa secara umum orang Korsika dianggal tidak bermoral karena mereka adalah bandit atau mereka adalah yang seringkali melakukan vendetta. Flaubert menyatakan bahwa sebetulnya itu tidak benar karena justru bandit yang direpresentasikan di Korsika sebetulnya adalah orang yang paling jujur, tidak seperti yang dibayangkan oleh orang Eropa pada umumnya. Konteks ini pun, Flaubert melakukan paradoksalitas. Di satu sisi ingin membela orang Korsika, tetapi masih tetap menempatkan mereka sebagai the other. Kata "our little European ideas" merupakan bentuk otherness terhadap orang Korsika yang masih menjadi liyan.

Sementara itu, Miss Lidya Nevil, meskipun dia adalah other dalam konteks Korsika karena memperjuangkan penolakan barbarisme yang menjadi simbol modernitas, di dalam cerita ia justru menjadi sentral ide baru karena menolak barbarisme. Selain itu, dia secara ide sudah berhasil mempengaruhi tokoh laki-laki agar tidak melakukan vendetta. Dapat dikatakan bahwa sebetulnya Orso tidak melakukan vendetta secara sengaja. Ia lebih sebagai seseorang yang membela diri karena terancam jiwanya. Digambarkan di dalam novel bahwa ketika berada di dalam hutan, dia diserang oleh dua anak Barricini.

Andre Durant (2006) dengan kajian sastra ekplikatif menjelaskan bahwa novel Prosper Merimée ini merupakan suatu bentuk penonjolan stereotip terhadap Korsika. Orang-orang Korsika dilabeli sebagai yang penuh dengan kekerasan dan melakukan bentuk-bentuk aktivitas yang barbar. Analisis sastra ini lebih menitikberatkan pada bagaimana dua saudara, yakni Orso dan adiknya, Colomba menunjukkan kekerasan 
yang distereotipkan sebagai bagian dari budaya Korsika. Lawan mereka adalah keluarga atas lainnya. Bisa dibayangkan jika keluarga atas atau elit Korsika saja melakukan tradisi kekerasan tersebut, maka orang-orang di kelas bawah juga akan semakin banyak yang melakukannya. Elegansi kelas atas, yang biasanya dihormati oleh kalangan atas di eropa untuk dilakukan dikritisi di dalam tulisan tersebut. Yang menjadi pertanyaan penting adalah, siapa yang bar bar di dalam cerita tersebut.

Lewat Colomba ini justru pengarang semakin menekankan ketidakmoralan orang Korsika lewat tokoh perempuan yang dibuat sebagai yang melakukan vendetta dan menentang hukum Prancis pada umumnya. Orso della Rebbia, kakaknya yang seorang serdadu Napoleon dan memahami peraturan negara menolak melakukannya. Dengan demikian, usaha pengarang menciptakan tokoh perempuan yang hadir sebagai subjek mengalami kegagalan karena justru bersifat paradoks. Perempuan yang disimbolkan sebagai yang kuat ini masih berada dalam batas periferi orang Eropa.

Selain itu, pengalaman pengarang tersebut mengalami exagerration atau penggambaran yang melebihi realitas. Max Gluckman (1955), seorang antropolog dan pendiri Manchaster School of Anthropology yang menulis mengenai vendetta di Korsika dalam tulisannya berjudul The Peace in the Feud menjelaskan bahwa vendetta ini merupakan sebuah praktik budaya atau tradisi yang berfungsi sebagai bentuk efektif untuk kontrol sosial. Tujuannya adalah untuk mengakhiri sebuah konflik individual atau konflik kelompok. Hal ini karena di dalam vendetta, satu nyawa akan dibayar dengan satu nyawa dan setelah itu konflik berakhir (Hardin, 1995). Menurut Gluckman, 20.000 laki-laki dan pemuda meninggal pada abad ke-19. Sementara itu menurut Dana dan Pauls (2008), 28.715 laki-laki dan pemuda dari populasi penduduk 120.000 (atau sekitar 23\%) penduduk Korsika meninggal sepanjang sejarah vendetta di Korsika dari tahun 1682 sampai 1714. Jadi, dalam hal ini yang andil dalam vendetta adalah laki-laki. Ketika Mérimée menggambarkan bahwa yang melakukan vendetta adalah perempuan, maka pengalaman yang dituangkan dalam sastra ini adalah bentuk melebih-lebihkan, yakni membuat perempuan lebih perkasa daripada laki-laki. Akan tetapi, hal ini menjadi paradoks karena perempuan yang dijelaskan itu menjadi tidak seperti pada gambaran nyata, yaitu sejarah sendiri mencatat para laki-lakilah yang melakukan vendetta.

Pengambaran perempuan sebagai yang keras, dan tidak berperikemanusiaan sebetulnya bukan merupakan hal baru dalam tradisi Barat yang kadang tidak disadari oleh para pembaca. Hampir semua cerita anak-anak ketika ingin menjelaskan baik dan buruk, hanya ada tiga figur: (1) laki-laki adalah perkasa sebagai penyelamat. (2) perempuan adalah lemah, cantik, dan akan ditolong oleh sang laki-laki. (3) nenek sihir perempuan merupakan sumber kejahatan (Udasmoro, 2011b). Orso adalah gambaran laki-laki yang kuat. Dia adalah seorang tentara Prancis pada masa Napoleon Bonaparte yang pulang ke daerahnya di Korsika setelah bergabung dengan militer Napoleon menguasai Eropa. Dengan demikian, dia adalah pahlawan. Selain itu, dia adalah tokoh yang dibuat sebagai yang memiliki kedisiplinan. Dia mematuhi aturan negara untuk tidak melanggar hukum, misalnya dengan menolak melakukan vendetta.

Sementara itu, Colomba tentu saja bukan tokoh lemah dan subordinat seperti dalam gambaran umum tokoh perempuan dalam cerita-cerita Eropa. Dia adalah yang kuat. Meskipun kekuatan itu dijustifikasi oleh Mérimée sebagai upaya balas dendam atas kematian orangtuanya, tetapi penggambaran tersebut justru lebih menjelaskan perempuan sebagai monster. Penggambaran perempuan sebagai monster ini sudah banyak dilakukan kajiannya dalam berbagai bidang kajian. Pada Sastra Inggris, misalnya, Sandra Gilbert dan Susan Gubar (1979) berargumen dalam buku mereka berjudul The Madwoman in the Attic: The Woman Writer and the Nineteenth-Century Literary Imagination bahwa perempuan di- 
gambarkan sebagai monster di banyak cerita terutama pada abad ke-19. Gilbert dan Gubar menganalisis novel karya Charlotte Bronte, yang berjudul Jane Eyre. Cerita-cerita dalam novel pada abad ke-19 memiliki dilema. Di satu sisi, ada usaha mengangkat kekuatan perempuan, tetapi di sisi lain, kekuatan tersebut menjadi bumerang untuk sekaligus mengkritisi kekuatan mereka itu sendiri.

Demikianpulahalnyadengan Colombadi dalam novel Mérimée. Colomba digambarkan sebagai perempuan yang bersikeras untuk melakukan vendetta tersebut sebagai upaya untuk membalaskan dendam keluarganya yang dalam tradisi Korsika seharusnya dilakukan oleh Orso kakaknya. Dalam hal ini ada proses maskulinisasi terhadap Colomba. Tugas maskulin yang seharusnya dijalankan oleh Orso sebagai laki-laki di dalam keluarga diambil alih oleh Colomba yang seorang perempuan sebagai yang memunculkan ide vendetta tersebut.

Selain membuat Colomba sebagai yang maskulin terjadi pembalikan terhadap tokoh maskulin, yakni terhadap Orso della Rebbia. Orso yang seorang serdadu digambarkan sebagai yang justru bersifat lemah dan tidak perkasa. Meskipun seorang serdadu, dia lebih emotif daripada Colomba. Dengan demikian, maskulinisasi terhadap tokoh perempuan menjelaskan pula ketidakberdayaan laki-laki Korsika. Ada semacam olok-olok terhadap kultur Korsika sendiri.

\section{SIMPULAN}

Sementara itu, keberadaan perempuan outsider yang lain, pada konteks cerita direpresentasikan oleh Miss Lidya, seakan memiliki legitimasi kekuasaan dan pengetahuan modernitas dengan menolak tindakan barbar vendetta dan berhasil mengubah mindset tokoh lelaki utama. Pada akhirnya, ide tersebut tidak sampai pada tujuannya karena pada akhirnya tokoh utama tetap membunuh musuh-musuh ayahnya. Para tokoh, yakni Colomba, Orso dan Lidya, tidak ada yang memenangkan kontestasi. Colomba tidak berhasil meyakinkan Orso melakukan vendetta karena Orso hanya membunuh karena membela diri, bukan untuk tujuan vendetta sebenarnya. Lidya, tidak berhasil sampai pada tujuan menghindari vendetta karena pada akhirnya Orso tetap membunuh. Demikian pula dengan Orso, dia tidak berhasil memenuhi keinginan dan perspektif barunya mengenai modernitas dengan menentang tradisionalitas. Pengarang memberi pesan bahwa tradisionalitas dan modernitas merupakan aspek yang selalu bersifat paradoks. Tradisionalitas, terutama dalam hal ini adalah tindakan barbarik vendetta, tidak mampu dilawan oleh rasio modernitas meskipun orang sudah hidup dalam kehidupan modern karena mindset tradisionalitas tersebut masih ada pada orang-orang yang hidup dalam kehidupan modern.

Dengan demikian, ada satu proses yang tumpang tindih antara menjadi laki-laki, menjadi perempuan, menjadi maskulin, menjadi feminin, menjadi tradisional, menjadi modern atau menjadi kelas atas atau kelas bawah. Tidak ada lagi yang mengikuti struktur sosial yang biasanya digambarkan dalam masyarakat patriarki. Bila dalam masyarakat modern yang hegemonic adalah laki-laki, maskulin, modern dan mewakili kelas privilege kalangan atas, maka di dalam novel Colomba ini ada pertanyaanpertanyaan baru. Yang hegemonik dalam persepsi modernitas adalah laki-laki, modern dengan bentuk maskulinitas yang berbeda dengan maskulinitas tradisional dan dapat berasal dari kalangan atas. Akan tetapi, pola ini dilawankan oleh pengarang dengan struktur baru, yaitu perempuan, maskulin, tradisional dan berasal dari kalangan kelas atas. Dari sini, terlihat ada sesuatu yang paradoks. Perempuan menjadi kuat tetapi harus melewati proses maskulinisasi. Mereka hanya dapat diakui kekuatannya apabila melalui proses maskulinisasi. 
DAFTAR PUSTAKA

Beauvoir, Simone. 1977. Le Deuxieme Sexe. Paris: Gallimard

Connell, R.W. 1995. Masculinities. Berkeley: University of California Press

Durant, Andre. 2006. "Prosper Mérimée" dalam www. le comptoirliitteraire. com.

Facaros, Dana \& Michael Pauls. 2008. Corsica. London: New Holland Publisher.

Friedan, Betty. 1963. Feminine Mystique. Norton and Company Inc.

Firestone, Shulamith. 1979. The Dialectic of Sex. New York: Free Press.

Gilbert, Sandra \& Susan Gubar. 2000. The Madwoman in the Attic: The Woman Writer and the Nineteenth-Century Literary Imagination. Yale: Yale University Press.

Gluckman, Max. 1955. "The Peace in the Feud" dalam Past and Present, Vol 8 (1):1-14 pp 56-70.

Haedens, Kléber. 1970. Une Histoire de la littérature française. Paris: Grasset.
Hardin, Russell. 1995. One for All: The Logic of Group Conflict. Princeton: Princeton University Press.

Holtman, Rober. B. 1979. The Napoleonic Revolution. Lousiana: LSU Press.

Mohanty T, Chandra. 1988. “Under Wester Eyes: Feminst Scholarship and Colonial Discourses". Dalam Feminist Review No 30 Automn. hlm 61-88.

Moller Okin. 1989. Justice, Gender and the Family. New York: Basic Book.

Pateman, Carole. 1988. The Sexual Contract. Standford: Standford University Press.

Udasmoro, Wening. 2011a. "Transformasi Identitas Perempuan dalam Sastra Prancis Abad ke-19" dalam Bunga Rampai Ulang Tahun Prof Chamamah ke-70. Yogyakarta: Universitas Gadjah Mada.

Udasmoro, Wening. 2011b. Sastra Anak dan Pendidikan Karakter. Yogyakarta: Sastra Prancis Universitas Gadjah Mada.

Walby. Sylvia. 1989. Theorising Patriarchy. New York: Sage Publication. 